\title{
STRATEGI KONTRAKTOR TERHADAP RESIKO SLF DENGAN POLA PEMBANGUNAN DI KOTA BANJARMASIN
}

\author{
Nanang Elva Julianoor Putra \\ Tenaga Ahli Kementerian PUPR wilayah Kalimantan Selatan \\ Tenaga Ahi DPR RI daerah pemilihan Kalimantan Selatan \\ Peneliti LP3KTK \\ E-mail : ir.nanangejp.sst.spp.mt@gmail.com/HP.+6281348988500
}

\begin{abstract}
ABSTRAK
Pemerintah Kota Banjarmasin mewajibkan seluruh bangunan harus memiliki Sertifikat Laik Fungsi (SLF) mulai tahun 2017. Ketentuan tentang SLF dalam pemberlakuannya dimulai sejak tahun 2010 sesuai Peraturan Undang Undang No.28 Tahun 2002 tentang Bangunan Gedung, dilanjutkan dengan ditindak lanjuti dalam Perda Kota Banjarmasin No. 15 Tahun 2012 dan Perwal Kota Banjarmasin No.65 Tahun 2016. Kondisi saat ini dalam pola pembangunan di Kota Banjarmasin, pemilik bangunan/pengguna jasa membayar $100 \%$ hasil pekerjaan kepada pihak pembangun/kontraktor sebelum bangunan itu mendapatkan SLF. Perihal adanya pemeriksaan kembali oleh Pemko Banjarmasin, bagaimana jika setelah proses pembangunannya bangunan tersebut dinyatakan belum mendapatkan SLF. Hal tersebut terindikasi akan adanya kerugian yang akan dialami oleh pemilik bangunan/pengguna jasa terkait biaya yang akan dikeluarkan pemilik untuk pemenuhan dari penilaian SLF. Tujuan penelitian ini adalah merumuskan strategi kontraktor terhadap resiko SLF dengan pola pembangunan di Kota Banjarmasin untuk menjamin bangunan tersebut mendapatkan SLF sesuai aturan yang berlaku dan pengguna jasa/pemilik bangunan tidak dirugikan.Penelitian menggunakan metode kuantitatif dan kualitatif, rumusan analisis wawancara, elemen aspek bobot penilaian SLF dan telaah dokumen aturan sesuai Permen PU, Perwal kota Banjarmasin. Hasil penelitian terhadap permasalahan resiko dampak dari penerapan SLF dapat digali sedini mungkin terhadap bobot penilaian SLF, karakteristik dari pola pembangunan dengan Perda menjadi inovasi dalam hal melibatkan point SLF sejak awal perencanaan dan dimuat dalam kontrak sebagai jaminan bangunan tersebut memperoleh SLF.
\end{abstract}

Kata kunci: Perda Walikota Banjarmasin, SLF, Dampak, Pola Pembangunan,

\begin{abstract}
Banjarmasin City Government requires that all buildings must have Functionality Certificate (SLF) starting in 2017. The provisions on SLF in its enforcement began in 2010 based on Law No.28 of 2002 on Building Structure, followed by follow up in Banjarmasin City Regulation no. 15 Year 2012 and Perwal Kota Banjarmasin No.65 Year 2016. The current condition in the pattern of development in Banjarmasin City, building owner / service users pay $100 \%$ of the work to the builder / contractor before the building gets SLF. Regarding the re-examination by Pemko Banjarmasin, what if after the construction process of the building stated not yet get SLF. This is indicated by the loss that will be experienced by the owner of the building / user services related
\end{abstract}


to the cost to be issued by the owner for the fulfillment of the SLF assessment. The objective of this research is to formulate contractor strategy to SLF risk with development pattern in Banjarmasin City to ensure the building get SLF as per applicable rules and service user / building owner is not harmed. The research uses quantitative and qualitative methods, interview analysis formulas, elemental aspects of SLF assessment weight and rule document review according to PU Permen, Perwal Banjarmasin. The results of the research on the impact risk problem of the SLF implementation can be extracted as early as possible on the SLF assessment weight, the characteristics of the development pattern with the local regulation become innovative in terms of involving SLF points from the beginning of planning and contained in the contract as a guarantee of the building obtaining SLF.

Keywords: Perda Mayor of Banjarmasin, SLF, Impact, Pattern of Development,

\section{PENDAHULUAN}

Pemerintah Kota Banjarmasin mewajibkan seluruh bangunan harus memiliki Sertifikat Laik Fungsi (SLF) mulai tahun 2017. Ketentuan tentang SLF dalam pemberlakuannya dimulai sejak tahun 2010 sesuai Peraturan UU No.28 Tahun 2002 tentang Bangunan Gedung, dilanjutkan dengan ditindak lanjuti dalam Perda Kota Banjarmasin No. 15 Tahun 2012 dan Perwal Kota Banjarmasin No.65 Tahun 2016. SLF adalah sertifikat yang diterbitkan oleh pemerintah daerah untuk gedung fungsi khusus oleh Pemerintah untuk menyatakan kelaikan fungsi suatu bangunan gedung baik secara administratif maupun teknis, sebelum pemanfaatannya. Kondisi saat ini dalam pola pembangunan di Kota Banjarmasin, pemilik bangunan/pengguna jasa membayar $100 \%$ hasil pekerjaan kepada pihak pembangun/kontraktor sebelum bangunan itu mendapatkan SLF. Perihal adanya pemeriksaan kembali oleh pemko Banjarmasin, bagaimana jika setelah proses pembangunannya bangunan tersebut dinyatakan belum mendapatkan SLF. Proses pembangunan terbagi dalam 3 tahapan yaitu pra kontruksi, konstruksi, dan pasca konstruksi. Tahapan pada pra konstruksi dokumen awal yang wajib dimiliki adalah Izin Mendirikan Bangunan (IMB) dan pada saat pasca konstruksi dokumen ahir yang wajib dimiliki adalah Sertifikat Laik Fungsi (SLF). Dalam hal lain, penilaian SLF terhadap bobot bangunan ada pada hasil pekerjaan kontraktor. Sedangkan kontraktor melakukan pekerjaan berpedoman kepada dokumen kontrak konstruksi yang ada. Kondisi kegiatan konstruksi yang sekarang, jelas berbeda dengan pola pembangunan yang lama. SLF jelas akan mempengaruhi pada pola pembangunan di kota Banjarmasin, dimana kegiatan kondisi konstruksi yang berjalan saat ini kedepan menjadi perhatian penting dalam penjamin kelaikan bangunan dengan waktu berkala sesuai peruntukannya. Dengan demikian, penelitian ini perlu menganalis dampak resiko dari pemberlakuan SLF terhadap kontraktor dan pemilik bangunan/pengguna jasa dengan pola pembangunan yang ada, menganalisis faktor yang menyebabkan bangunan belum mendapat SLF, dan bagaimana strategi dalam proses pembangunan agar bangunan mendapatkan SLF dengan pemilik bangunan tidak dirugikan. Sehingga kedepan, SLF terhadap pengguna jasa dan pelaku jasa konstruksi bisa sebagai dasar pertimbangan dalam kegiatannya.

\section{Rumusan Masalah}

Permasalahan yang akan diteliti sesuai dengan fokus penelitian yaitu: 
1. Apa dampak resiko dari diberlakukannya SLF terhadap kontraktor dan pemilik bangunan/pengguna jasa dengan pola pembangunan yang ada?

2. Faktor yang dapat menyebabkan bangunan gedung belum mendapatkan SLF setelah dibangun?

3. Bagaimana strategi dalam proses pembangunan agar bangunan mendapatkan SLF dengan pemilik bangunan/jasa tidak dirugikan?

\section{Tujuan Penelitian}

Penelitian ini untuk menemukan tujuan yaitu:

1. Menemukan dampak resiko dari diberlakukannya SLF terhadap kontraktor dan pemilik bangunan/pengguna jasa dengan pola pembangunan yang ada

2. Faktor yang dapat menyebabkan bangunan gedung belum mendapatkan SLF setelah dibangun

3. Membuat strategi dalam proses pembangunan, agar bangunan mendapatkan SLF dengan bagaimana pemilik bangunan/pengguna jasa tidak dirugikan

\section{TINJAUAN PUSTAKA}

\section{Tinjauan Umum Sertifikat Laik Fungsi Bangunan Gedung}

Permen P.U No. 25/PRT/M/2007 Tentang Sertifikat Laik Fungsi Bangunan Gedung dijelaskan Sertifikat Laik Bangunan Gedung adalah sertifikat yang diterbitkan oleh Pemerintah daerah kecuali untuk gedung fungsi khusus dari Pemerintah untuk menyatakan kelaikan fungsi suatu bangunan gedung baik secara administratif maupun teknis sebelum pemanfaatannya. Pada peraturan penyelenggaraan bangunan gedung ijin SLF baru diperoleh setelah pelaksanaan gedung selesai dari hasil pemeriksaan oleh pemda/kota, sementara ada ijin - ijin lain seperti ijin IMB dalam proses penyelenggaraan bangunan gedung. Secara teori sertifikasi didefinisikan sebagai tanda atau surat pernyataan tertulis atau tercetak dari orang berwenang yang dapat digunakan dengan bukti suatu kejadian, keterkaitan dengan sertifikat yang diterbitkan oleh pemerintah disini adalah Pemko Banjarmasin sebagai penyelenggara aturan peraturan Walikota No. 65 Thn 2016 Tentang Ketentuan Penyelenggaraan Izin Mendirikan Bangunan, Sertifikat Laik Fungsi, Tim Ahli Bangunan Gedung dan Pendataan Bangunan Gedung. Laik berdasarkăn KBBI (kamus besar Bahasa Indonesia) didefinisikan sebagai memenuhi persyaratan yang ditentukan atau yang harus ada, baik kepatutan, pantas dalam kategori terhadap objek benda. Hubungan dengan masyarakat sebagai pengguna bangunan maupun pemilik bangunan yang menyerahkan pembangunan terhadap kontraktor terhadap bangunannya, hendaknya bangunan tersebut memenuhi persyaratan yang ditentukan dalam penilaian Pemko Banjarmasin. Fungsi menurut menurut KBBI (kamus besar Bahasa Indonesia) adalah sekolompok aktivitas yang tergolong pada jenis yang sama berdasarkan sifat atau pelaksanaanya dengan berhubungan dengan bagian dari suatu sistem yang lebih besar, hubungan dalam penyelenggaraan bangunan yang diatur oleh Pemerintah terhadap bangunan gedung yang diharapkan sesuai kegunaan dan pemanfaatan bangunan setelah selesai dibangun. Bangunan adalah struktur buatan manusia yang terdiri atas dinding dan atap yang didirikan secara permanen di suatu tempat. Bangunan juga biasa disebut dengan rumah dan gedung, yaitu segala sarana, prasarana atau infrastruktur dalam kebudayaan atau kehidupan manusia dalam membangun peradabannya. Gedung adalah bangunan tembok dan sebagainya yang berukuran besar sebagai tempat kegiatan, seperti 
perkantoran, pertemuan, perniagaan, pertunjukan, olahraga, tempat tinggal, dan sebagainya.

\section{Peraturan mengenai SLF Berdasarkan Undang-Undang Republik Indonesia}

Peraturan Pemerintahan Republik Indonesia Nomer 36 Tahun 2005 Tentang Peraturan Pelaksanaan UU No. 282002 Tentang Bangunan Gedung Laik fungsi disebutkan adalah suatu kondisi bangunan gedung yang memenuhi persyaratan administrasi dan persyaratan teknis sesuai dengan fungsi bangunan gedung yang ditetapkan.

\section{Peraturan mengenai SLF Berdasarkan Peraturan Menteri Dalam Negeri}

Menurut Peraturan Menteri Pekerjaan Umum No.25/PRT/M/2007 Tentang Pedoman Sertifikat Laik Fungsi Bangunan Gedung pada ketentuan umum disebutkan beberapa pengertian.Sertifikat Laik Fungsi Bangunan Gedung adalah sertifikat yang diterbitkan oleh pemerintah daerah kecuali untuk bangunan gedung fungsi khusus oleh Pemerintah untuk menyatakan kelaikan fungsi suatu bangunan gedung baik secara administrative maupun teknis, sebelum pemanfaatannya.

\section{Peraturan mengenai SLF Berdasarkan Peraturan Walikota Banjarmasin}

Peraturan Walikota Banjarmasin No. 65 Tahun 2016 Tentang Ketentuan Penyelenggaraan Izin Mendirikan Bangunan Gedung, Sertifikat Laik Fungsi, Tim Ahli Bangunan Gedung, dan Pendataan Bangunan Gedung. Sertifikasi Laik Fungsi yang selanjutnya disingkat SLF adalah sertifikasi yang diterbitkan oleh Walikota atau pejabat yang ditunjuk berdasarkan hasil pemeriksaan kelaikan fungsi bangunan gedung baik secara administrasi maupun teknis untuk dapat dimanfaatkan. Ketentuan penyelenggaraan SLF, setiap bangunan gedung wajib memiliki SLF. Walikota menerbitkan SLF untuk bangunan gedung yang telah memenuhi persyaratan kelaikan fungsi bangunan gedung. Hal ini sesuai dengan Undang-undang no. 28 tahun 2002 tentang Bangunan Gedung dimana Pemerintah daerah menerbitkan sertifikat laik fungsi yang telah selesai dibangun dengan telah memenuhi persyaratan kelaikan fungsi bangunan gedung sebagai syarat untuk dapat digunakan dan dimanfaatkan terhadap bangunan gedung itu sendiri.

\section{Bangunan Gedung}

Pada peraturan Walikota Banjarmasin No. 65 Tahun 2016 bagian kedua klasifikasi Bangunan Gedung untuk Penyelenggaraan SLF Pasal 13 menyebutkan;

1. Klasifikasi bangunan gedung untuk penyelenggaraan SLF meliputi:
a. bangunan gedung umumnya; dan
b. bangunan gedung untuk kepentingan umum.

2. Bangunan gedung pada umumnya disebutkan sebagaimana dimaksud pada ayat (1) meliputi:

a. bangunan gedung hunian rumah tinggal tunggal sederhana dan rumah deret sederhana;

b. bangunan gedung hunian rumah tinggal tunggal dan rumah deret dengan ketinggian sampai dengan 2 (dua) lantai; dan

c. bangunan gedung hunian rumah tinggal tidak sederhana dengan ketinggian lebih dari 1 (satu) lantai dan bangunan gedung lainnya pada umumnya 
JURNAL KACAPURI

JURNAL KEILMUAN TEKNIK SIPIL

Volume 3 Nomor 1 Edisi Juni 2020

Tabel 1. Pengolongan SLF

\begin{tabular}{|c|c|c|c|}
\hline $\begin{array}{l}\text { KELOMPOK } \\
\text { BANGUNAN } \\
\text { GEDUNG }\end{array}$ & $\begin{array}{l}\text { TIPE } \\
\text { SLF }\end{array}$ & KOMPLEKSITAS & $\begin{array}{l}\text { PELAKSANAAN } \\
\text { PENGAWASAN } \\
\text { KONSTRUKSI }\end{array}$ \\
\hline $\begin{array}{l}\text { BANGUNAN } \\
\text { GEDUNG BARU }\end{array}$ & \multirow[t]{2}{*}{$\begin{array}{l}\text { PENERBITAN SLF1 } \\
\text { (PERTAMA KALI) }\end{array}$} & SEDERHANA & $\begin{array}{l}\text { DILAKUKAN OLEH } \\
\text { PENYEDIA JASA }\end{array}$ \\
\hline $\begin{array}{l}\text { BANGUNAN } \\
\text { GEDUNG EKSISTING }\end{array}$ & & $\begin{array}{l}\text { TIDAK } \\
\text { SEDERHANA }\end{array}$ & $\begin{array}{l}\text { DESAIN PROTOTIPE } \\
\text { PELAKSANA OLEH }\end{array}$ \\
\hline \multirow[b]{2}{*}{$\begin{array}{l}\text { BANGUNAN } \\
\text { PRASARANA }\end{array}$} & \multirow{2}{*}{$\begin{array}{c}\text { PENERBITAN SLF1 } \\
\text { (PERTAMA KALI) } \\
\text { DAN } \\
\text { PENERBITAN SLFn } \\
\text { (PERPANJANGAN) }\end{array}$} & & PEIVILIK \\
\hline & & KHUSUS & $\begin{array}{c}\text { DESAIN, } \\
\text { PENGAWASAN, DAN } \\
\text { PELAKSANAOLEH } \\
\text { PEMILIK }\end{array}$ \\
\hline
\end{tabular}

Sumber : BP2TNPM Kota Banjarmasin

\section{Persiapan/Syarat pengurusan SLF di Kota Banjarmasin}

Setiap bangunan gedung baru selesai dibangun atau eksisting harus memiliki SLF sebelum pemanfaatan, SLF diperoleh dengan mengajukan permohonan SLF kepada dinas PUPR kecuali untuk bangunan rumah tinggal ke DPMPTSP. Permohonan diajukan oleh pemohon, yaitu pemilik bangunan gedung atau orang yang diberi kuasa oleh pemilik bangunan gedung. Permohonan SLF harus memenuhi persyaratan teknis dan administrative, SLF diterbitkan terhadap bangunan gedung yang telah memenuhi persyaratan kelaikan fungsi berdasarkan hasil pemeriksaan kelaikan fungsi bangunan gedung. Penyedia jasa pengaji teknis bangunan gedung melakukan pemeriksaan kelaikan fungsi bangunan gedung, kecuali bangunan rumah tinggal 1 (satu) lantai oleh tim teknis DPMPTSP. Tim DPMPTSP beranggotakan pegawai ASN dari Dinas PUPR yang diwakili oleh TABG.

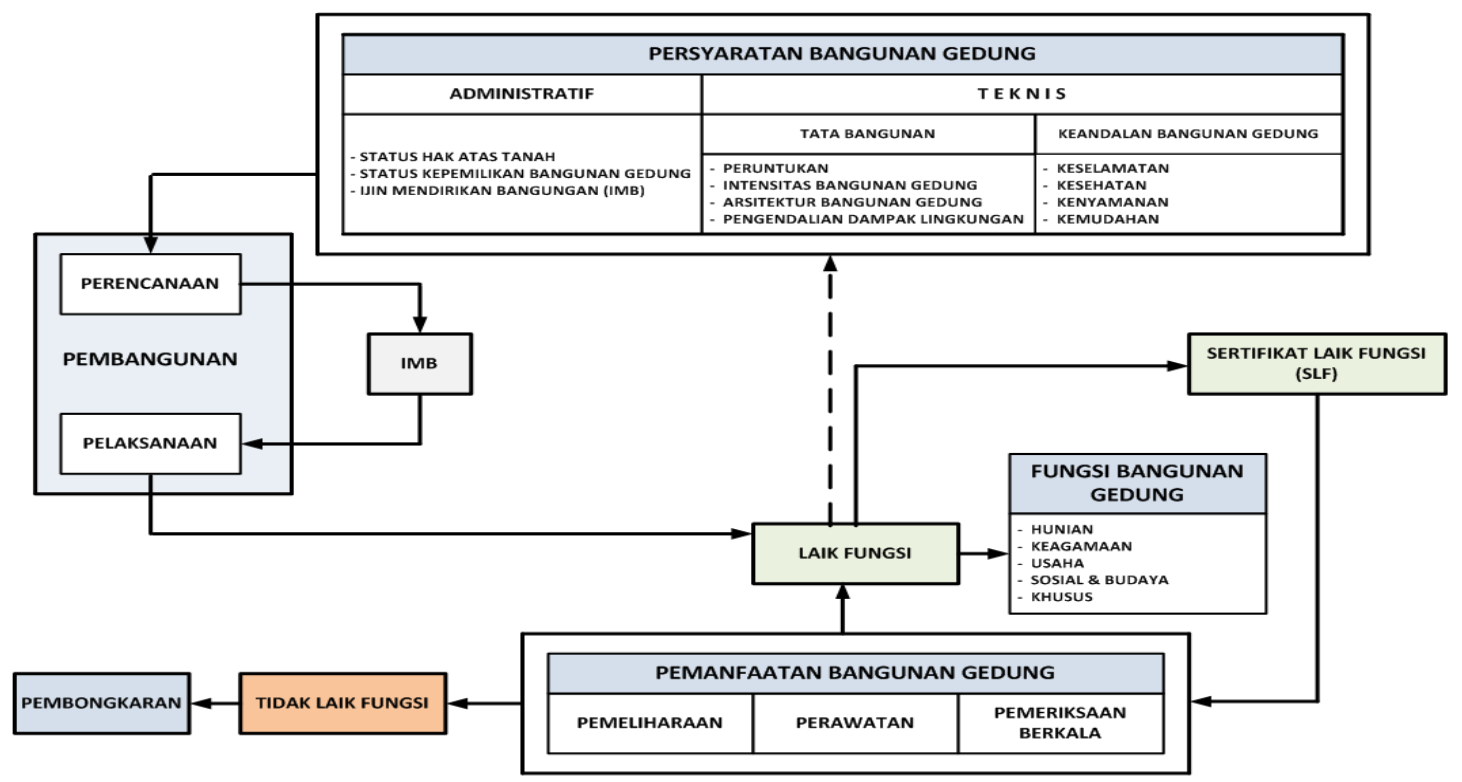

Gambar 1. Keterkaitan Proses Bangunan Gedung Terhadap Proses Administrasi Sumber : Ir. Kimmy S. Juwana, MSEA 
JURNAL KACAPURI

JURNAL KEILMUAN TEKNIK SIPIL

Volume 3 Nomor 1 Edisi Juni 2020

\section{Karakteristik Pembangunan}

Hubungan keterkaitan dalam karakteristik pembangunan umumnya adanya kegiatan proyek konstruksi yang dibangun, dimana dalam kegiatan dimulai dari perencanaan, pelaksanaan pengawasan serta pemeliharaaan. Hal tersebut bisa berbentuk administrasi dan teknis kegiatan.

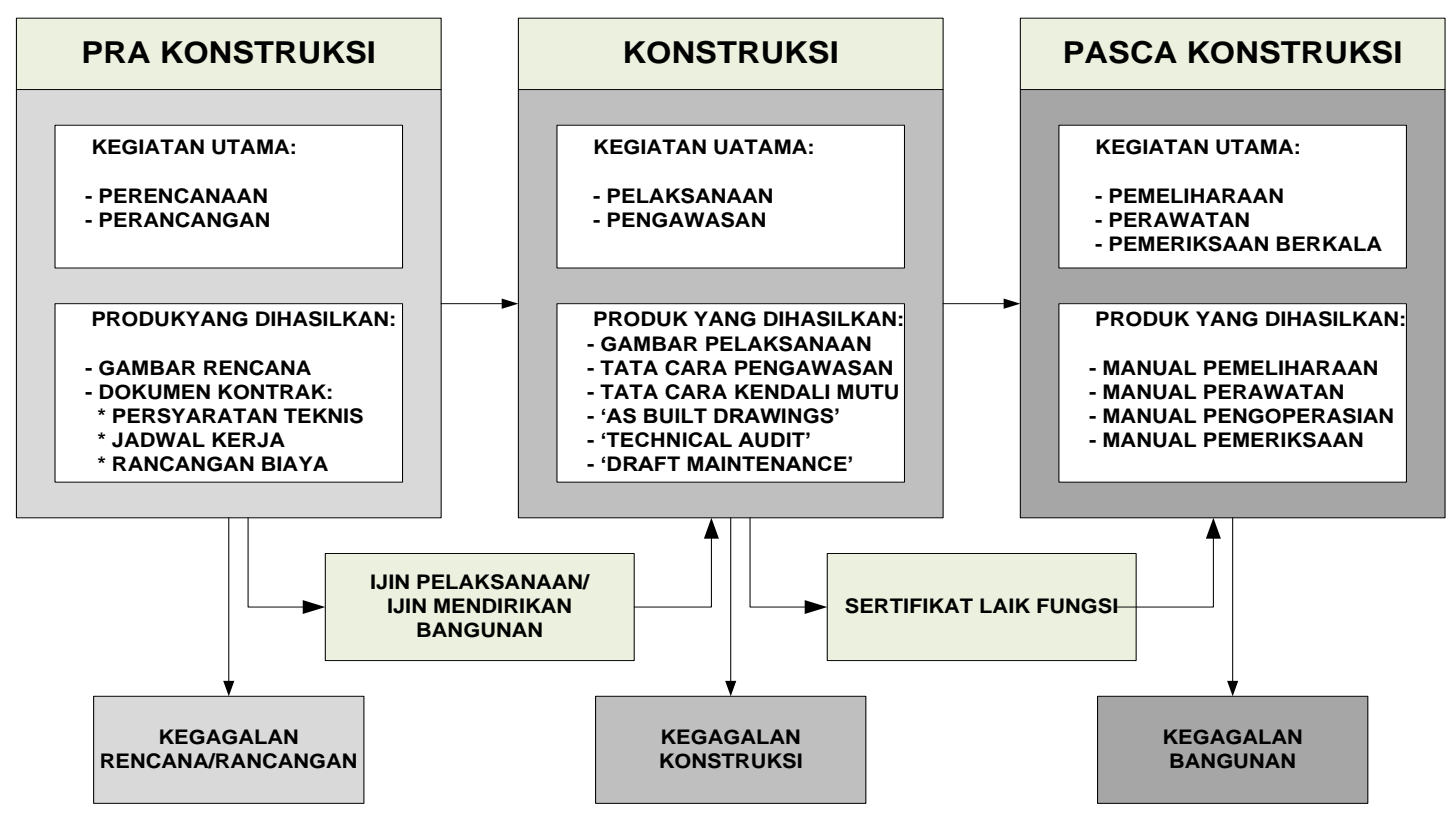

Gambar 2. Keterkaitan Penyelenggara Bangunan Gedung

\section{Biaya restribusi SLF}

Permen PU No. 25/PRT/M/2007 Tentang Pedoman Sertifikat Laik Fungsi Bangunan Gedung, SLF bangunan gedung sebagai keterangan yang menyatakan bahwa pelaksanaan pembangunan bangunan gedung telah memenuhi persyaratan dan ketentuan dalam IMB untuk dapat dimanfaatkan sesuai dengan fungsinya, sehingga tidak dikenakan biaya lagi.

\section{Aspek dan Elemen Penilaian SLF}

Pelaksanaan Pasal 16 PP 36/2005 menjadi pemeriksaan keandalan bangunan gedung terbagi dalam lima aspek, yakni: arsitektur, struktur, utilitas dan proteksi kebakaran, aksebilitas, serta penataan banguna dan lingkungan. Kenyamanan dimasukan dalam aspek arsitektur, karena memeriksa pelapis muka lantai, dinding, plafong, pintu/jendela, dan atap. Bagian ini akan memberikan kenyamanan bagi penghuni/pemakai bangunan. Keselamatan dimasukan dalam aspek strukutur, karena memeriksa pondasi, dinding, kolom-kolom, slab lantai, rangka atap, dan dilatasi bangunan. Bagian inilah yang dapat menjamin keselamatan bangunan dari kerusakan. Keselamatan digolongkan dalam aspek utilitas dan proteksi kebakaran, karena memeriksa alarm, sprinkle, hidran, apar, lift/escalator, air bersih/kotor, listrik, tata udara, proteksi petir, dan instalasi komunikasi. Dengan terkendalinya bagian ini akan menjadikan keselamatan bagi bangunan gedung. Kemudahan sudah mempertimbangkan bagi semua orang termasuk yang digolongkan dalam aspek 
aksebilitas, karena memeriksa ukuran dasar ruang, jalur pedestrian/ram, toilet, pintu, lift/tangga aksesibel. Bagian inilah yang dilihat untuk memastikan kemudahan bangunan gedung. Dalam pelaksanaan pemeriksaan keandalan bangunan dilengkapi dengan kepastian hukum karena akan berkaitan dengan masyarakat. Kepastian hukum dimasukan dalam aspek penataan bangunan dan lingkungan, karean memeriksa peruntukan lahan, koefisien dasar bangunan, koefisien lantai/ketinggian bangunan dan garis sempadan.

\section{Aspek Arsitektur.}

Menurut petunjuk teknis pemeriksaan keandalan bangunan Departemen PU (1998), aspek arsitektur yakni memeriksa pelapis permukaan lantai/dinding, dibagi menjadi ruang dalam dan ruang luar. Ruang dalam terdiri: kesesuian penggunaan fungsi, pelapis muka lantai, pelapis plesteran lantai, plesteran muka dinding, pelapis plesteran dinding, pintu dan jendela, pelapis muka langit-langit. Sedangkan ruang luar terdiri dari: muka langit-langit, kusen, kaca, talang/jurai, dan paving blok.

\section{Aspek Struktur}

Menurut petunjuk teknis pemeriksaan keandalan bangunan gedung Departemen PU (1998), aspek struktur yaitu berhubungan dengan kekuatan konstruksi bangunan gedung, dibedakan menjadi empat bagian yang masing-masing terdiri struktur bawah, atas, dan pelengkap.

a. Struktur Rangka Beton Praktis dan Dinding Pasangan, stuktur bawah: pondasi, kepala pondasi, balok pondasi. Struktur atas: dinding pasangan bata/batako, kolom, balok praktis, slab lantai, slab atap, rangka atap, ikatan angin, gording. Struktur pelengkap:rangka langit-langit, penutup langit-langit, tangga, lantai bawah, dan pagar.

b. Struktur Rangka Baja dan Dinding Pasangan, Struktur bawah: pondasi, kepala pondasi, balok pondasi,. Struktur atas: joint kolom balok, kolom baja, balok baja, pengaku silang, slab lantai, rangka atap, ikatan langit, gording. Struktur pelengkap: penggantung langit-langit, dinding pasangan bata/batako, shotcare panel precast, balok anak, laufel, kanopi, tangga.

c. Struktur Rangka Beton dan Dinding Geser terdiri, struktur bawah: pondasi kepala pondasi, balok pondasi. Struktur atas: joint kolom balok, kolom, dinding geser, slab lantai, slab atap, rangka atap, ikatan angin, gording. Struktur pelengkap: penggantung langit-langit, dinding pasangan bata/batako, balok anak, laufel, kanopi tangga.

d. Struktur Rangka Beton dan Dinding Pasangan terdiri dari, struktur bawah: pondasi, kepala pondasi, balok pondasi. Struktur atas: joint balok, kolom, balok, slab lantai, slab atap, rangka atap, ikatan angin, gording. Struktur pelengkap: penggantung langit-langit, dinding pasangan bata/batako, balok anak, laufel, kanopi, tangga.

\section{Aspek Utilitas dan Proteksi Kebakaran}

Menurut petunjuk teknis pemeriksaan keandalan bangunan gedung Departemen PU (1998), aspek Utilitas dan Proteksi Kebakaran adalah sarana-sarana pelengkap/penunjang supaya penghuni bangunan gedung dapat beraktifitas dan pencegahan serta penanggulangan terhadap bahaya kebakaran, pemeriksa terdiri atas: 
a. Instalasi pencegahan kebakaran: alarm, sprinkler, gas pemadam api, hidran, tabung apar.

b. Transportasi vertical - lift: motor penggerak, sangkar \& alat control, motor pintu, kabel \& panel listrik, rel penyeimbang sangkar, peredam sangkar. Eskalator: motor penggerak, alat control, kabel dan panel listrik, rantai penarik, roda gigi penarik, badan escalator, anak tangga/lantai.

c. Plambing - Air Bersih: sumber air, penampung air, tangki air atas/menara, pompa penampung dan alat, pompa distributor dan alat, listrik panel pompa, pompa instalasi, kran. Air kotor: kloset/urinoir, saluran ke septic, kran air gelontor, tangki septic, bak cuci, saluran bak cuci, lubang/penguras, pipa air hujan.

d. Instalasi listrik - Sumber PLN: panel teg, menegah, trafo, panel teg, tengah, panel distribusi, lampu, armature, kabel instalasi. Sumber Genset: motor penggerak, alternator, pengisi aki, radiator/pendingin, kabel instalasi, AMF, daily tnak, panel.

e. Tata udara, AC - Sentral: system pendingin langsung, system pendingin tidak langsung. Non sentral: system AC window, system AC split.

f. Instalasi Penangkal Petir - Produksi Petir Eksternal: kepala penangkal petir, hantaran pembumian, elektroda pembumian. Proteksi petir: arrester tegangan lebih, pengikat ekuipotensial, hantaran pembumian, elektroda pembumian.

g. Instalasi Komunikasi - telepon: telepon, PABX, kabel instalasi. Tata suara: mikropon, panel system tata suara, speker, kabel instalasi.

\section{Aspek Aksesibilitas}

Menurut petunjuk teknis pemeriksaan keandalan bangunan gedung Departemen PU (1998), aspek aksesibilitas adalah penyediaan sarana dan prasarana/tempat untuk memberikan kemudahan bagi semua orang guna mencapai dan beraktifitas di bangunan gedung. Dilakukan pemeriksaan terhadap:

a. Ukuran ruang: luasan minimal.

b. Jalur pedestrian/ram - Permukaan: stabil, kuat, tahan cuaca, tekstur halus tidak licin, ukuran searah $120 \mathrm{~cm}$ dan dua arah $160 \mathrm{~cm}$, bebas benda penghalang, miring maks, 1:8, jarak $900 \mathrm{~cm}$ ada bidang datar, cahaya terang. Drainase: dalam $\leq 1,5$ $\mathrm{cm}$, mudah dibersihkan, dekat dengan tepi ram. Jalur pemandu: ubin (guiden blok), tempat/pasangan sesuai.

c. Area parkir - Parkir kendaraan: posisi $\leq 60 \mathrm{~cm}$ dari tujuan, dekat pedestrian, ada ruang bebas, penanda khusus, terhubung ram/fasilitas lain, ukuran tunggal $370 \mathrm{~cm}$ dan ganda $620 \mathrm{~cm}$. Area naik-turun: panjang minimal $600 \mathrm{~cm}$, ram, pedestrian, rambu, kemiringan $1: 11$.

d. Alat Kontrol - Alat peyandang cacat: stop kontak/tombol mudah dijangkau, rambu, peringatan darurat: suara, visual, getaran.

e. Toilet: rambu, toilet duduk, handrail/tisu/shower terjangkau, lantai tidak licin, pintu dibuka dari luar, posisi strategis, tombol darurat.

f. Pintu: mudah dibuka penca, lebar $\min .90 \mathrm{~cm}$, dekat pintu tidak ada ram/beda tinggi, plat tending/tenggang waktu tutup 3 menit pintu otomatis.

g. Lift aksesibilitas: beda muka lantai bangunan dengan lift $\leq 1,25 \mathrm{~cm}$, lebar ruang tunggu $\geq 185 \mathrm{~cm}$, tinggi tombol $90-11-\mathrm{cm}$, panel huruf braile, indicator suara, indicator visual, handrail, sarana komunikasi, waktu pintu terbuka $\geq 3$ menit.

h. Telpon: lokasi aksesible, ruang gerak cukup, mudah dijangkau kursi roda (80$110 \mathrm{~cm})$, panjang kabel cukup, control volume suara, rambu telepon teks, buku telepon braile berisyarat suara. 
i. Lift Tangga: beda lift ke tempat duduk $\geq 60 \mathrm{~cm}$, lebar tempat duduk $\geq 40 \mathrm{~cm}$, tombol mudah dilihat/dijangkau, tombol pada sandaran tangan huruf braile, miring rel penggantung $=$ miring tangga, rel penggantung kuat.

\section{Aspek Penataan Bangunan dan Lingkungan}

Menurut petunjuk teknis pemeriksaan keandalan bangunan gedung Departemen PU (1998), Aspek ini lebih pada kesesuian bangunan dan tapak persilnya terhadap peraturan bangunan setempat. Untuk itu dilakukan pemeriksaan kesesuaian terhadap:

a. Rencana kota/penggunaan bangunan: peruntukan lahan

b. Koefisien dasar bangunan: perbandingan luas bangunan dan luas lahan

c. Koefisien lantai bangunan: jumlah lantai dan ketinggian bangunan

d. Garis sempadan bangunan: jarak bangunan dari sempadan.

\section{METODE PENELITIAN}

Pendekatan yang diambil untuk menjawab penelitian terhadap rumusan masalah pada dampak resiko dari pemberlakuan SLF terhadap kontraktor dan pemilik bangunan/pengguna jasa dengan pola yang ada adalah dengan melalui persepsi/pemahaman. Persepsi yang dimaksud adalah pemahaman pelaku jasa konstruksi dan pemilik bangunan/pengguna jasa terhadap SLF, hal tersebut dapat ditempuh dengan penelitian bahwa responden dari pelaku jasa konstruksi dan pemilik bangunan/pengguna jasa diindikasikan oleh persepsi/pemahaman. Pendekatan yang diambil untuk menjawab penelitian terhadap rumusan masalah pada faktor yang dapat menyebabkan bangunan gedung belum mendapatkan SLF setelah di bangun adalah dengan melalui mengetahui penilaian Tim teknis TABG Kota Banjarmasin terhadap Bangunan Gedung, hal tersebut dapat ditempuh dengan penelitian bahwa responden dari TABG Kota Banjarmasin di indikasikan oleh berdasarkan penilaian Tim. Dari dua rumusan pendekatan yang ada, pendekatan yang diambil untuk menjawab penelitian terhadap membuat strategi dalam proses pembangunan, agar bangunan mendapatkan SLF dengan bagaimana pemilik bangunan/pengguna jasa tidak dirugikan adalah dengan merumuskan hasil dari pendekatan pemahaman kontraktor \& pengguna jasa/pemilik bangunan dengan penilaian oleh TABG Kota Banjarmasin. 
JURNAL KACAPURI

JURNAL KEILMUAN TEKNIK SIPIL

Volume 3 Nomor 1 Edisi Juni 2020

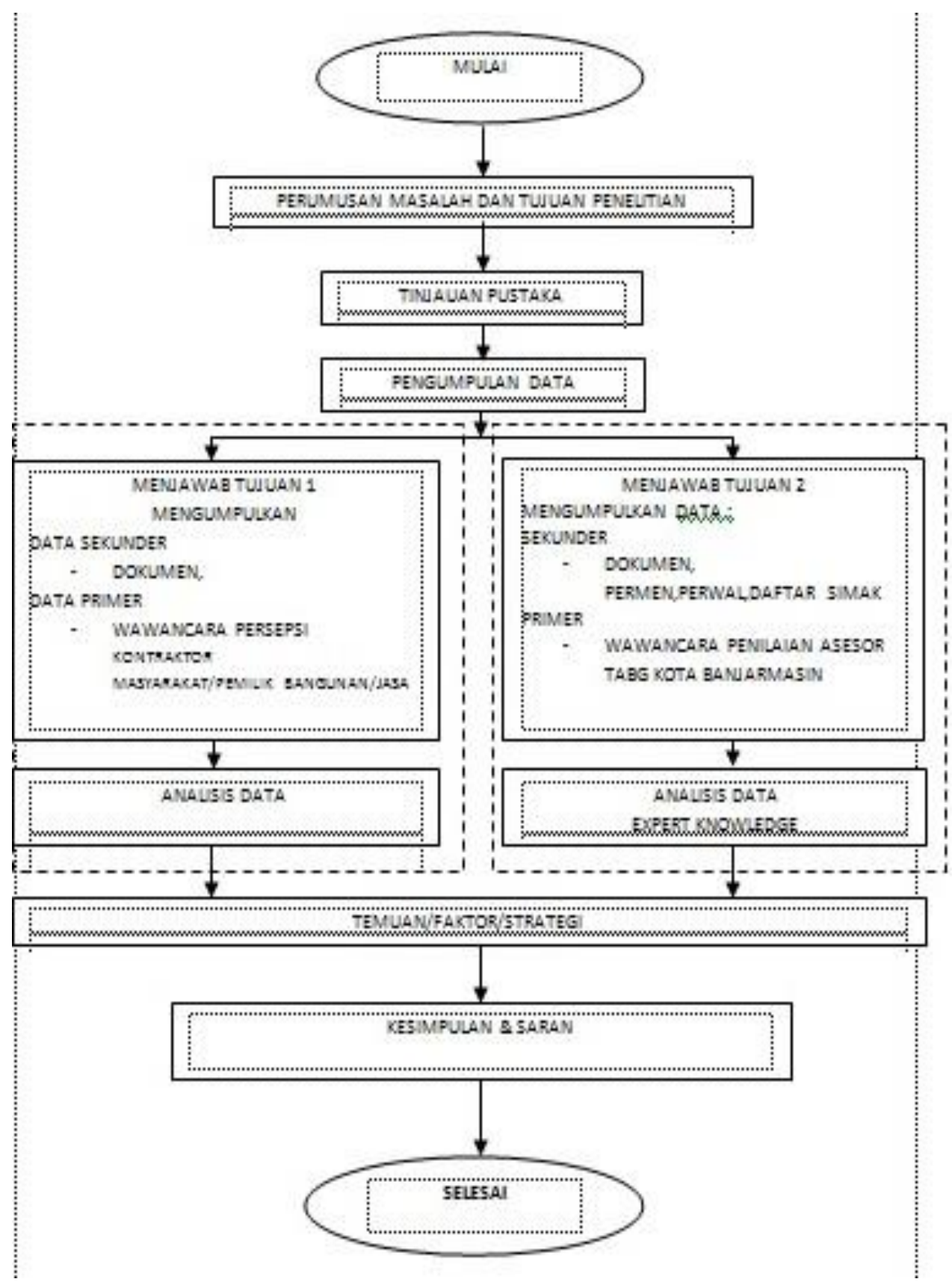

Gambar 3. Diagram Alir Penelitian

Sumber : Analisis, 2020

\section{Variabel Penelitian}

Tahapan identifikasi variable:

a. Untuk dapat mengukur persepsi pemahaman pelaku jasa konstruksi dan masyarakat terkait SLF dengan menilai dari sosialisasi Pemerintah terkait pemberlakuan Perwal Kota Banjarmasin No. 65 tahun 2016.

b. Untuk dapat menjawab rumusan pada tujuan faktor yang dapat menyebabkan bangunan belum mendapat SLF setelah dibangun, dengan menggali informasi penilai dari Tim teknis penilai SLF dengan menyandingkan aturan yang sudah ditetapkan Departemen PU. 


\title{
Indikator Variabel Penelitian
}

Di dalam penelitian ini dikembangkan dengan analisis yang menggambarkan persepsi pemahaman responden atas item-item pertanyaan yang di ajukan.

\section{Penilaian persepsi pelaku jasa konstruksi}

\author{
Nilai \\ $10 \%$ \\ $0 \%$
}

1. Tahu

2. Tidak Tahu

\section{Penilaian persepsi masyarakat/pengguna jasa}

1. Tahu

Nilai

2. Tidak Tahu

$10 \%$

$0 \%$

Insrumen wawancara yang diajukan untuk mendapat tujuan persepsi pemahaman kontraktor \& masyarakt dengan berkaitan dalam hubungan SLF, adapun terkait contoh alur pertanyaan untuk persepsi pemahaman yang akan digunakan:

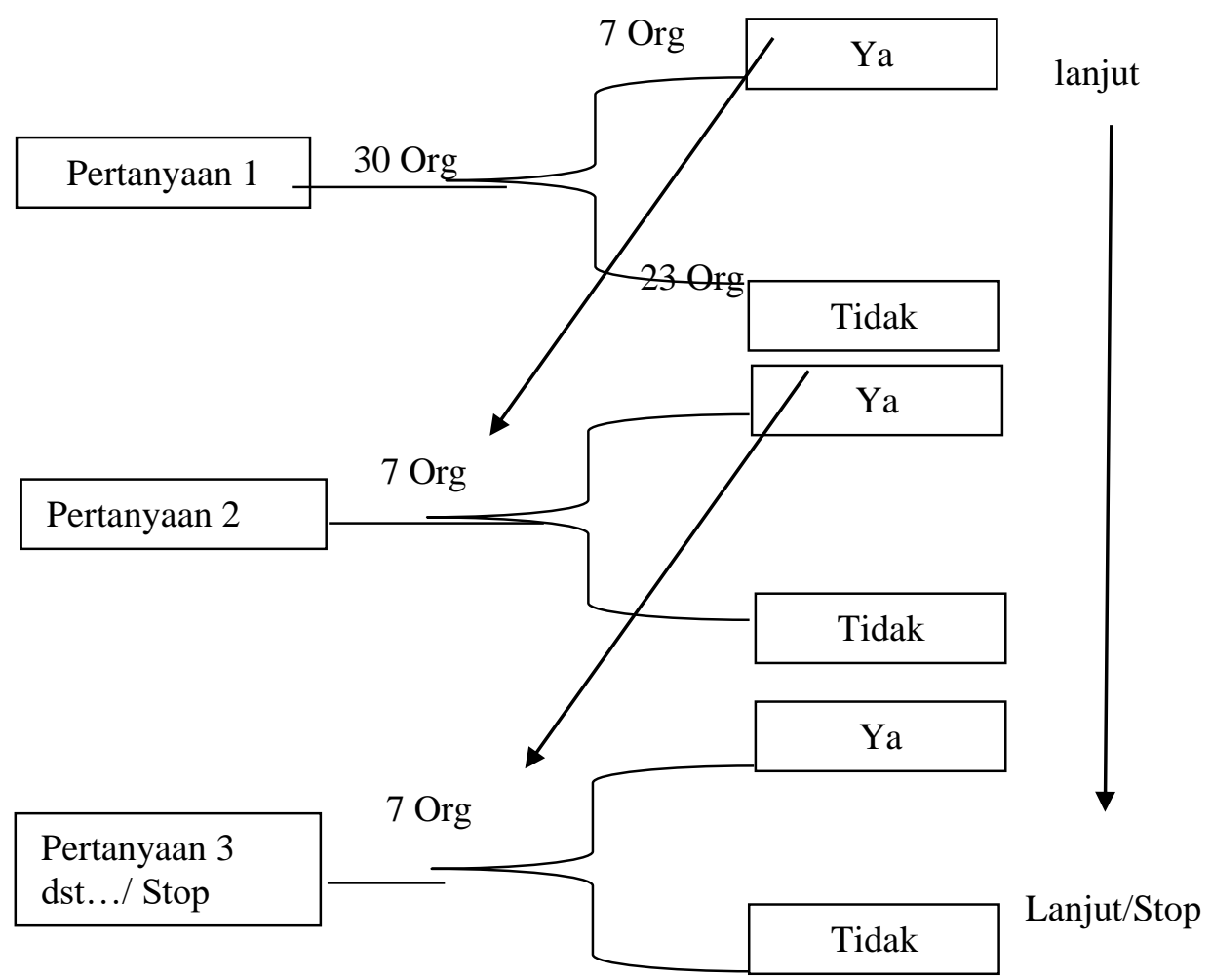

Gambar 4. Skema Wawancara terhadap Responden

Pada penjabaran gambar di atas adalah rangkaian wawancara pada beberapa instrumen wawancara yang sudah disiapkan terkait di tanyakan kepada responden untuk menggali pemahaman dari kontraktor 30 org dan pengguna jasa/pemilik bangunan 30 org terkait SLF, jika pada pertanyaan pertama dari jumlah responden didapati mengetahui terkait SLF, maka pertanyaan mendalam akan ditanyakan selanjutnya untuk menggali lebih jauh. Jika pada pertanyaanya selanjutnya didapat jawaban tidak maka pertanyaan dihentikan dengan mengambil informasi yang sudah didapat.

\section{Metode pengumpulan data}

Teknik pengumpulan data yang digunakan dengan melakukan penelitian ini 
menggunakna interview (wawancara). Wawancara merupakan cara pengumpulan data dengan memberikan beberapa pertanyaan yang dianggap penting langsung dari sumbernya dalam menunjang penyusunan penelitian ini. Wawancara ini digunakan untuk mengetahui hal-hal yang berkaitan dengan responden secara lebih terperinci. Dalam melakukan wawancara terhadap responden atau yang mewakili, hendaknya memiliki kreteria sebagai berikut:

a. Memiliki pengalaman dibidang konstruksi

b. Memiliki pengetahuan dan pendidikan yang menunjang

c. Memiliki reputasi yang baik

d. Memiliki pengamatan yang baik terhadap konstruksi

e. Memiliki kemampuan dalam bidang konstruksi yang di akui oleh pemerintah Kota Banjarmasin berdasarkan SK penunjukan Walikota Banjarmasin

f. Pemilik bangunan/pengguna bangunan/pengguna jasa

\section{Teknik Pengumpulan Data}

Dalam penelitian ini dilakukan teknik pengumpulan data dengan membuat dua metode survey, sebagai berikut.

a. Survei primer. Survei yang meninjau secara langsung kondisi lapangan penelitian guna mencari data-data eksisting yang mendukung penelitian. Metode yang dilakukan dalam pengumpulan data survei primer meliputi teknik observasi dan interview.

b. Survei Sekunder. Pengumpulan data sekunder didapat dengan diperoleh melalui telaah dokumen. Teknik ini dilakukan untuk memperoleh data-data sekunder yang berbentuk dokumen yang berkaitan dengan penerbitan SLF di Kota Banjarmasin, daftar simak yang digunakan tim penilai teknis pekerjaan dan Kontrak konstruksi pembangunan yang digunakan saat ini.

\section{Area Penelitian \& Objek Populasi}

Pada area penelitian berada di wilayah Kota Banjarmasin Prov. Kalimantan Selatan yang berlaku penetapan Perwal No. 65 tahun 2016 Tentang ketentuan penyelenggaraan izin mendirikan bangunan gedung, sertifikat laik fungsi, tim ahli banguna gedung dan pendataan bangunan gedung. Objek populasi yang akan di teliti adalah subjek yang berada pada suatu wilayah dan memenuhi kaitan dengan masalah yang di teliti, dalam penelitan yang akan di lakukan penelitian adalah pelaku jasa konstruksi (kontraktor) TABG Kota Banjarmasin dan masyarakat. Penentuan sampel pada penelitian ini menggunakan cara non probability sampling (judgedment sampling). Dipilih sampel berdasarkan penilain peneliti bahwa responden merupakan adalah pihak yang baik sebagai dijadikan sampel penelitian. Jumlah responden terdiri dari pelaku jasa konstruksi kontraktor sebanyak 30 perusahaan yang dipilih dari 130 kontraktor yang terdaftar di GAPENSI aktip Kota Banajrmasin, Tim teknis Pemerintah Kota Banjarmasin sebanyak 5 orang sesuai SK Walikota Banjarmasin yang ditunjuk sebagai penilai SLF, \& masyarakat dimana sebagai pemilik bangunan dan pengguna jasa 30 orang.

\section{Analisis Wawancara}

Expert Knowledge dalam system informasi hal yang biasa untuk membedakan antara data, informasi dan pengetahuan. Istilah data mengacu kepada angka (atau bukan angka) tanda-tanda tersebut dengan sendirinya tidak mempunyai arti apapun. 
Bentuknya dapat berupa keadaan nyata yang tersusun sedemikian rupa sehingga ada artinya bagi seseorang yang menerimanya. Pengetahuan mempunyai beberapa definisi diantaranya adalah informasi yang tersusun yang dapat digunakan untuk pemecahan masalah. Data, informasi, dan pengetahuan dapat digolongkan dalam tingkatan atau derajat abstrak jumlahnya (gambar.3.2). Pengetahuan kebanyakan bentuknya adalah abstrak dan sangat sedikit jumlahnya.

\section{HASIL DAN PEMBAHASAN}

Dalam mendapatkan hasil analisis dari strategi kontraktor terhadap resiko SLF dengan pola pembangunan di Kota Banjarmasin, maka perlu dilakukan analisis meliputi data baik yang sekunder maupun yang primer. Data sekunder adalah telaah dokumen terkait dasar ketetapan bangunan gedung yang wajib ber SLF yang termuat dalam UU, Permen PU, Perwal Kota Banjarmasin dan modul pemeriksaan keandalan bangunan berupa daftar simak yang digunakan oleh tim teknis Pemko Banjarmasin. Untuk data Primer adalah hasil dari kegiatan wawancara terhadap Pelaku jasa konstruksi, pemilik bangunan/pengguna jasa dan TABG Kota Banjarmasin.

\section{Narasumber wawancara}

Menjawab pertanyaan dampak resiko dari diberlakukannya SLF terhadap kontraktor dan pemilik bangunan/pengguna jasa dengan pola pembangunan yang ada, analisis dilakukan berdarkan pemahaman persepsi terkait SLF dengan jumlah responden sebagai berikut :

Responden dipilih random dengan data sebagai berikut :
1. Kontraktor $=30$ org

2. Pemilik bangunan/pengguna jasa $=30 \mathrm{org}$

Menjawab dari faktor yang dapat menyebabkan bangunan gedung belum mendapatkan SLF setelah dibangun, maka dilakukan analisis wawancara terhadap responden 5 orang yang sudah di tunjuk Walikota Banjarmasin sebagai tim Penilia SLF pada Bangunan Gedung di Kota Banjarmasin.

\begin{tabular}{|c|c|c|c|}
\hline Narasumber & 1 & $\begin{array}{l}\text { Nama } \\
\text { Jabatan }\end{array}$ & $\begin{array}{l}\text { Joni Irawan } \\
\text { Tim Ahli Bangunan Gedung Kota Banjarmasin } \\
\text { Spesialis Struktur (HAKI) }\end{array}$ \\
\hline \multirow[t]{2}{*}{ Narasumber } & 2 & Nama & Ahmad Marzuki \\
\hline & & Jabatan & $\begin{array}{l}\text { Tim Ahli Bangunan Gedung Kota Banjarmasin } \\
\text { Spesialis Pondasi Geoteknik (HATTI) }\end{array}$ \\
\hline \multirow[t]{2}{*}{ Narasumber } & 3 & Nama & Deddy Iskandar \\
\hline & & Jabatan & $\begin{array}{l}\text { Tim Ahli Bangunan Gedung Kota Banjarmasin } \\
\text { Spesialis Arsitektur (IAI) }\end{array}$ \\
\hline \multirow[t]{2}{*}{ Narasumber } & 4 & Nama & H. Syamsudi \\
\hline & & Jabatan & $\begin{array}{l}\text { Tim Ahli Bangunan Gedung Kota Banjarmasin } \\
\text { Spesialis ME (AITEI) }\end{array}$ \\
\hline \multirow[t]{2}{*}{ Narasumber } & 5 & Nama & Jabir \\
\hline & & Jabatan & $\begin{array}{l}\text { Tim Ahli Bangunan Gedung Kota Banjarmasin } \\
\text { Spesialis Tata Ruang }\end{array}$ \\
\hline
\end{tabular}


Hasil Persepsi Responden \& Pendapat Narasumber

Hasil analisis pemahaman persepsi terkait SLF sebagai berikut:

Tabel 4.1 Tabel hasil analisis pemahaman SLF terhadap responden

\begin{tabular}{|c|c|c|c|c|}
\hline No & Profesi & $\begin{array}{c}\text { Jumlah } \\
\text { responden }\end{array}$ & Bobot \% & Ket \\
\hline 1 & Kontraktor & 30 & $70 \%$ & Tidak tahu SLF \\
\hline 2 & $\begin{array}{c}\text { Pemilik } \\
\text { bangunan/pengguna jasa }\end{array}$ & 30 & $100 \%$ & Tidak Tau SLF \\
\hline
\end{tabular}

Tabel 4.2 Tabel hasil analisis pemahaman SLF terhadap responden

\begin{tabular}{|c|c|c|c|c|}
\hline No & Profesi & $\begin{array}{c}\text { Jumlah } \\
\text { responden }\end{array}$ & Bobot \% & Ket \\
\hline 1 & Kontraktor & 30 & $30 \%$ & Tahu SLF \\
\hline 2 & $\begin{array}{c}\text { Pemilik } \\
\text { bangunan/pengguna jasa }\end{array}$ & 30 & $0 \%$ & Tau SLF \\
\hline
\end{tabular}

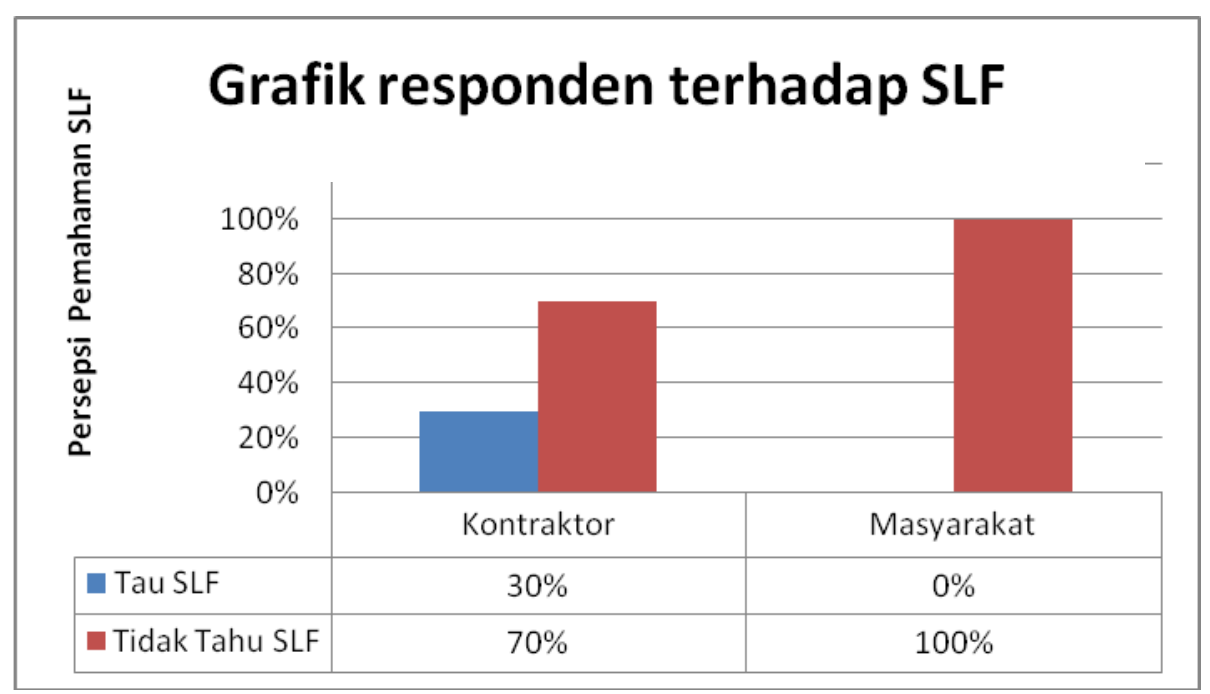

Gambar 4.1 Hasil analisis pemahaman SLF terhadap responden berupa grafik

Hasil analisis pada gambar 4.1 dimana persepsi/pemahaman SLF untuk pelaku jasa konstruksi dari 30 kontraktor hanya 30\% yang mengetahui dan $70 \%$ nya tidak tahu, dan dari 30 pengguna jasa/pemilik bangunan $100 \%$ tidak tahu terkait apa itu SLF. Hal ini mengindentifikasikan bahwa persepsi terhadap SLF \& terkait Perwal Banjarmasin No.65 Tahun 2016 belum familiar dan diketahui oleh elemen pelaku pembangunan yang ada di Kota Banjarmasin terhadap kontraktor \& masyarakat si pengguna jasa/pemilik bangunan. Dalam hal lain, Pemerintah mengimplementasikan Permen P.U No. 25/PRT/M/2007 Tentang Sertifikat Laik Fungsi Bangunan Gedung tidak akan tercapai terkait hasil dari proses pola pembangunan yang ada. Terhadap regulasinya, aspek dari elemen pelaku pembangunan menjadi perhatian penting dan fokus Pemerintah terkait pemahaman dari regulasi yang ditetapkan harus seimbang. 
JURNAL KACAPURI

Tabel 4.3 Tabel hasil analisis penilaian SLF TABG Kota Banjarmasin

\begin{tabular}{|c|c|c|c|c|c|c|c|}
\hline NO & Pertanyaan & $\begin{array}{l}\text { Narasumber } \\
1 \\
\text { Ya/Tidak }\end{array}$ & $\begin{array}{c}\text { Narasumber } \\
2 \\
\text { Ya/Tidak }\end{array}$ & $\begin{array}{c}\text { Narasumber } \\
\mathbf{3} \\
\text { Ya/Tidak }\end{array}$ & $\begin{array}{c}\text { Narasumber } \\
\mathbf{4} \\
\text { Ya/Tidak }\end{array}$ & $\begin{array}{c}\text { Narasumber } \\
5 \\
\text { Ya/Tidak }\end{array}$ & $\begin{array}{c}\text { Rangkuman } \\
\text { Ya/Tidak }\end{array}$ \\
\hline 1 & $\begin{array}{l}\text { Apa dampak } \\
\text { penerapan SLF } \\
\text { terhadap pola proses } \\
\text { pembangunan } \\
\text { gedung di Kota } \\
\text { Banjarmasin } \\
\text { menjamin bangunan } \\
\text { tersebut terhadap } \\
\text { pemanfaatannya? }\end{array}$ & $\mathrm{Ya}$ & $\mathrm{Ya}$ & $\mathrm{Ya}$ & $\mathrm{Ya}$ & $\mathrm{Ya}$ & $\begin{array}{l}\text { Ya, semua sepakat } \\
\text { dampak penerapan } \\
\text { SLF terhadap pola } \\
\text { proses pembangunan } \\
\text { gedung di Kota } \\
\text { Banjarmasin } \\
\text { menjamin bangunan } \\
\text { tersebut terhadap } \\
\text { pemanfaatannya }\end{array}$ \\
\hline 2 & $\begin{array}{l}\text { Apa faktor dokumen } \\
\text { administrasi, kualitas } \\
\text { bangunan, } \\
\text { pemahaman pelaku } \\
\text { pembangunan } \\
\text { terhadap SLF dapat } \\
\text { menyebabkan } \\
\text { bangunan belum } \\
\text { mendapatkan SLF } \\
\text { setelah di bangun? }\end{array}$ & $\mathrm{Ya}$ & $\mathrm{Ya}$ & $\mathrm{Ya}$ & $\mathrm{Ya}$ & $\mathrm{Ya}$ & $\begin{array}{l}\text { Ya, semua sepakat } \\
\text { faktor dokumen } \\
\text { administrasi, kualitas } \\
\text { bangunan, } \\
\text { pemahaman pelaku } \\
\text { pembangunan } \\
\text { terhadap SLF dapat } \\
\text { menyebabkan } \\
\text { bangunan belum } \\
\text { mendapatkan SLF } \\
\text { setelah di bangun }\end{array}$ \\
\hline 3 & Dari penilaian suatu & $\mathrm{Ya}$ & $\mathrm{Ya}$ & $\mathrm{Ya}$ & $\mathrm{Ya}$ & $\mathrm{Ya}$ & Ya, semua sepakat 2 \\
\hline
\end{tabular}


JURNAL KACAPURI

JURNAL KEILMUAN TEKNIK SIPIL

Volume 3 Nomor 1 Edisi Juni 2020

\begin{tabular}{|c|c|c|c|c|c|c|c|}
\hline & $\begin{array}{l}\text { bangunan, apakah } 2 \\
\text { aspek Struktur \& } \\
\text { Utilitas proteksi } \\
\text { kebakaran yang } \\
\text { dominan lebih tinggi } \\
\text { untuk bangunan } \\
\text { mendapatkan SLF? }\end{array}$ & & & & & & $\begin{array}{lr}\text { aspek } & \text { Struktur \& } \\
\text { Utilitas proteksi } \\
\text { kebakaran yang } \\
\text { dominan lebih tinggi } \\
\text { untuk bangunan } \\
\text { mendapatkan SLF }\end{array}$ \\
\hline 4 & $\begin{array}{lr}\text { Apakah } & \text { semua } \\
\text { elemen dari } & \text { masing- } \\
\text { masing } & \text { bobot } \\
\text { penilaian } & \text { sangat } \\
\text { berpengaruh } & \text { dari } \\
\text { penilaian? } & \\
\end{array}$ & $\mathrm{Ya}$ & $\mathrm{Ya}$ & $\mathrm{Ya}$ & $\mathrm{Ya}$ & $\mathrm{Ya}$ & $\begin{array}{l}\text { Ya, semua sepakat } \\
\text { semua elemen dari } \\
\text { masing-masing bobot } \\
\text { penilaian sangat } \\
\text { berpengaruh dari } \\
\text { penilaian }\end{array}$ \\
\hline 5 & $\begin{array}{lr}\text { Apa } & \text { rekomendasi } \\
\text { dan } & \text { strategis } \\
\text { penerapan SLF } & \text { agar } \\
\text { tecapai bisa } & \text { dengan } \\
\text { sosialisai } & \text { terkait } \\
\text { pemahaman } & \text { SLF } \\
\text { kepada masyarakat } \\
\text { dan pelaku jasa } \\
\text { konstruksi } & \text { yang } \\
\text { perlu ditingkatkan } \\
\text { serta } & \text { adanya } \\
\text { pengikat jaminan }\end{array}$ & Ya & Ya & $\mathrm{Ya}$ & $\mathrm{Ya}$ & $\mathrm{Ya}$ & 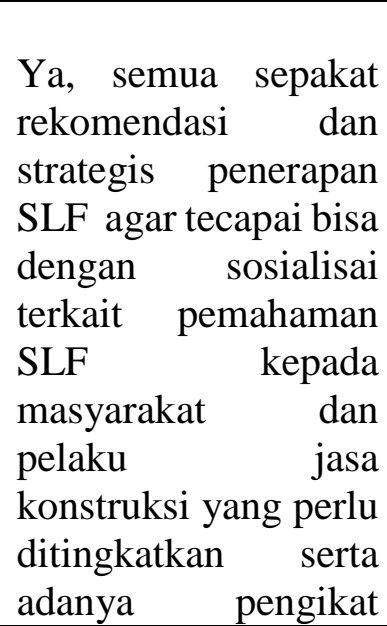 \\
\hline
\end{tabular}


JURNAL KACAPURI

JURNAL KEILMUAN TEKNIK SIPIL

Volume 3 Nomor 1 Edisi Juni 2020

\begin{tabular}{|l|l|l|l|l|l|}
\hline $\begin{array}{l}\text { bangunan dalam } \\
\text { proses } \\
\text { pelaksanaanya } \\
\text { dijamin } \\
\text { mendapatkan SLF } \\
\text { oleh dipelaksana ? }\end{array}$ & & & $\begin{array}{l}\text { jaminan } \\
\text { dalam } \\
\text { pelaksanaanya } \\
\text { dijamin mendapatkan } \\
\text { SLF oleh dipelaksana } \\
\text { proses }\end{array}$ \\
\hline
\end{tabular}

Hasil analisis wawancara terkait menjawab faktor bangunan belum mendapatkan SLF pada Tabel 4.3, dimana responden dari TABG

Kota Banjarmasin sepakat terkait perihal pertanyaan yang diajukan. 


\section{Elemen SLF}

Departemen Pekerjaan Umum membuatkan model pemeriksaan bangunan gedung yang di uji coba di kota-kota seluruh Indonesia. Sebagai langkah awal pemeriksaaan bangunan gedung perlu di identitas bangunan gedung seperti: nama bangunan, fungsi, luas, jenis lantai, pemilik, tahun dibangun, rencana usia bangunan, imb, perencanaan, kontraktor, pengawas, dan nilai bangunan. Lima aspek pemeriksaan keandalan bangunan gedung yakni: arsitektur, struktur, utilitas dan proteksi kebakaran, aksebilitas, dan penataan bangunan dan lingkungan. Tahap ini berfungsi mengumpulkan data/informasi dan mulai mengkopilasi data.

1. Arsitektur umumnya melihat pelapis permukaan lantai/dinding yang dibagi menjadi: (a) ruang dalam dan (b) ruang luar.

2. Aspek Struktur yaitu berhubungan dengan kekuatan konstruksi bangunan gedung. Struktur sangat penting karena tanpa struktur yang kuat bangunan bangunan gedung akan runtuh. Dilatasi bangunan merupakan hal penting karena atau kaidah struktur yang harus menjadi perhatian. Pemeriksaan meliputi empat bagian yaitu: (a) Rangka struktur pada beton praktis dan dinding pasangan, (b) struktur pada rangka baja dan dinding pasangan (c) struktur rangka beton dan dinding geser (d) Struktur rangka beton dan pada pasangan dinding.

3. Aspek Utilitas dan Proteksi Kebakaran adalah sarana-sarana penunjang supaya penghuni dapat beraktivitas dan pencegah serta penanggulan kebakaran, meliputi: (a) instalasi pencegahan (b) transportasi vertical (c) plambing (d) instalasi listrik (e) tata udara, AC (f) instalasi instalasi penangkal petir, dan ( $\mathrm{g}$ ) instalasi komunikasi adalah bagian dai aspek utilitas dan proteksi kebakaran.

4. Aspek Aksebilitas adalah penyedia sarana dan tempat untuk kemudahan semua orang guna mencapai dan beraktifitas di bangunan gedung. Dilakukan pemeriksaan terhadap (a) ukuran ruang (b) jalur pedestrian/ram (c) parkir (d) perlengkapan (e) toilet (f) pintu (g) lift (h) telpon.

5. Pemeriksaan dokumen terhadap (a) rencana kota/penggunaan bangunan (b) dasar bangunan pada koefisien, dan (c) lantai bangunan pada koefisien, dan (d) bangunan pada garis sempadan. Keempat bagian ini merupakan Aspek Penataan Bangunan dan Lingkungan, aspek ini lebih pada kesesuaian bangunan dan tapaknya terhadap peraturan

\section{Bobot penilaian SLF}

Tabel 4.4 Bobot masing-masing aspek keandalan

\begin{tabular}{|c|c|c|c|c|c|c|c|}
\hline \multirow{2}{*}{ No } & \multirow{2}{*}{ Oleh } & \multicolumn{5}{|c|}{ Rata-rata bobot per aspek masing-masing } \\
\cline { 3 - 7 } & Arsitektur & $\begin{array}{c}\text { Struk- } \\
\text { tur }\end{array}$ & $\begin{array}{c}\text { Utilitas } \\
\text { \& Proteksi } \\
\text { Kebakaran }\end{array}$ & Aksesblts & PBL & Nilai \\
\hline 1 & Departemen PU & $10 \%$ & $30 \%$ & $50 \%$ & $5 \%$ & $5 \%$ & $100 \%$ \\
\hline
\end{tabular}

\section{Pelaku pembangunan}

Konsultan Perencana pada tahapan awal perencanaan bangunan gedung, keterkaitan penilaian terhadap aspek SLF harus menjadi perhatian dan pertimbangan awal, bukan hanya pada design namun juga pada dokumen spek steknis yang dipakai nantinya.

Pelaksana bangunan kontraktor, design yang sudah mendapatkan IMB oleh pemda hendaknya tidak ada perubahan dan mutu yang sudah ditetapkan tidak kurang dari batas toleransi, jika kontraktor dalam bekerja menempatkan pekerjaan teknis dan administrasi dikelola dengan dengan baik, maka capaian terkait pemenuhan SLF mestinya dapat terwujud.

Pemilik bangunan harus menyepakati dan mematuhi IMB yang sudah diberikan, terkait hal lain adanya perubahan ketika berjalannya pekerjaan mestinya menyesuaikan aspek SLF untuk 
diperhatikan dan komitmen terhadap kontrak yang disepakati. Pemerintah terhadap regulasi yang sudah ditetapkan hendaknya memperhatikan pemahaman terkait Peraturan yang sudah ditetapkan apakah sudah benar-benar di ketahui oleh elemen dari pelaku pembangunan.

\section{Pola pembangunan}

Saat ini pihak kontraktor tidak pernah memberi jaminan bahwa bangunan tersebut setelah dibangun mendapatkan SLF, hal ini berpotensi kerugian dari pemilik dan akan adanya resiko yang dialami oleh kontraktor sebagai pelaksanan bangunan terkait sebagai pelaksana. Pihak owner pun harus menyepakati hasil dari pekerjaan kontraktor yang sudah tertuang dalam kontrak selama tidak ada permintaan perubahan design oleh owner, maka jelas isi dalam kontrak kedepan juga berpengaruh sebagai penjamin pekerjaan kontraktor. Faktor aspek tertinggi dalam penilaian SLF ada di Aspek Struktur dan Utilitas, Elemen yang dominan pada penilaian bangunan setelah berdiri menjadi perhatian penting dalam proses pembangunan. Jika bangunan selesai dibangun belum mendapatkan SLF sesuai aturan, maka akan ada surat teguran untuk pemenuhan perbaikan agar memperoleh SLF. Hal lain jika bangunan tersebut tidak segera memperbaiki sesuai aturan, akan ada kemungkinan bangunan tersebut terkana sanksi administrative hingga sampai tahap pembongkaran. Kendala lain ada di administrasi IMB, untuk bangunan baru tidak ada kendala banyak, hanya saja pada bangunan lama nantinya jelas terjadi kendala terhadap banguan yang sudah lama berdiri namun belum memilik SLF, hal itu jelas akan menjadi kendala nantinya terhadap pemenuhan administrative pengajuan SLF. SLF adalah hasil rekomendasi dari pemeriksaan keandalan bangunan oleh TABG Kota Banjarmasin setelah proses pembangunan selesai, maka perhatian lain ada pada hasil pekerjaan jika ijin IMB sudah keluar.

\section{Kesimpulan}

\section{PENUTUP}

Dampak risiko dari diberlakukannya SLF terhadap kontraktor dan pemilik bangunan/pengguna jasa dengan pola pembangunan di Kota Banjarmasin saat ini adalah:

1. Bangunan gedung yang tidak memperhatikan aspek penilaian SLF dengan kesesuaian mutu bangunan yang sudah direncanakan, maka bangunan sudah jelas gagal fungsi dan belum bias mendapatkan SLF.

2. Adanya perbaikan/pemenuhan yang diminta oleh Tim Teknis penilai SLF, terkait bangunan yang belum lulus uji SLF.

3. Akan adanya ongkos tambahan yang dikeluarkan si pemilik bangunan/pengguna jasa untuk memenuhi SLF.

4. Sanksi berupa teguran, administratif, sampai pada tahap pembongkaran jika pemenuhan perbaikan belum juga dipenuhi.

5. Dalam proses perijinannya, IMB dan SLF terpisah. Sehingga bangunan yang mendapatkan IMB belum tentu mendapatkan ijin SLF.

6. Faktor yang menyebabkan bangunan gedung belum mendapatkan SLF setelah dibangun adalah:

7. Ketidaksesuaian IMB yang diberikan terhadap bangunan gedung yang di bangun.

8. Kualitas bangunan gedung terhadap Aspek penilaian SLF,

9. Ketidaktahuan pelaku pembangunan terhadap SLF Bangunan Gedung

10. Administrasi perijinan dimana IMB yang belum terkait secara langsung dengan proses penerbitan SLF.

11. Tidak lengkapnya proses administrasi saat pengajuan SLF.

12. Faktor terbesarnya adalah pelaksana pembangunan yaitu kontraktor yang belum memberikan jaminan bangunan dapat langsung mendapat SLF setelah selesai.

13. Strategi dalam proses pembangunan agar bangunan mendapatkan SLF dengan pemilik bangunan/pengguna jasa tidak dirugikan adalah: 
14. Sosialisai penerapan Perwal Banjarmasin No. 65 tahun 2016 kepada masyarakat, pengguna jasa/pemilik bangunan, pelaku jasa konstruksi dan pemerintah terkait pemahaman SLF lebih dimaksimalkan.

15. Dalam struktur dan utilitas, aspek struktur harus ditegaskan dalam dokumen perencanaan terkait masalah adiminstrasi IMB. Jika 2 aspek ini tercukupi saat bangunan selesai, maka berpeluang besar memperoleh SLF di samping aspek lain yaitu arsitektur, ME \& Penataan bangunan lingkungan.

16. Kontraktor harus memberikan jaminan dalam kontrak pelaksanaan bahwa bangunan memenuhi aspek SLF setelah selesai dibangun, dimana jaminan bangunan tertuang didalam kontrak konstruksi/RKS.

\section{Saran-saran}

Untuk mencapai keberhasilan SLF perlu perhatian pada proses pembagunan saat pelaksanaan yang dilakukan oleh kontraktor sebagai jaminan bangunan laik fungsi, sehingga perhatian terbesar adalah pada kontrak konstruksi dengan mempertimbangkan aspek-aspek penilaian dalam SLF.

Diperlukan penelitian lanjutan terutama berkaitan dengan model kontrak yang mendukung SLF secara keselurahan, sehingga dapat menjamin bangunan yang selesai dibangun mendapatkan Sertifikat Laik Fungsi (SLF).

\section{DAFTAR PUSTAKA}

Amri Sjafie (2006), Teknologi Audit Forensik, Repair dan Retrofit Untuk Rumah \& Bangunan Gedung. Yayasan John Hi-The Ideatama. Jakarta.

Ari Wibowo (2011), Dirut Antara Minta Sistem Keselamatan Gedung Diperkuat. Artikel Antara.

Departemen Pekerjaan Umum, 1998. Petunjuk Teknis Tata Cara Pemeriksaan Keandalan Bangunan Gedung. Jakarta

Erna Kristnanto (2009), Pemahaman pelaku jasa konstruksi dalam proses pembangunan. Artikel penelitian Universitas Pendidikan Indonesia.

Gagoek Hardiman. (2006). Kenyamanan dan keamanan Bangunan Ditinjau Dari Kondisi Tapak, Bahan dan Utilitas. Jurnal Vol.5 Edisi I 2006. Program Magister Arsitek Pascasarjana Universitas Diponogoro.

Ismail Febrin Anas, Hakam and Fauzan (2011), Kerusakan Bangunan Hotel Bumi Minang Akibat Gempa Padang 30 September 2009. Jurnal ISSN 0853-2982. Jurusan Teknik Sipil Universitas Andalas.

Kristanto Erna (2009), Keandalan Struktur Bangunna Terhadap Gempa Bumi Pada Bangunan Rumah Tinggal Padat Penduduk di Perkotaan. Artikel Penelitian Universitas Pendidikan Indnesia.

Kristiawan (2011), Kompatibilitas Susut Antara Material Perbaikan dan Beton . Jurnal ISSN 0853-2982. Jurusan Teknik Sipil Universitas Sebelas Maret.

Lestari Fatma (2008), Audit sarana prasarana pencegahan penanggulangan dan tanggap darurat kebakaran digedung fakultas X Universitas Indonesia tahun 2006. Makalah teknologi Volume 12, No.1 April 2008:55-60. Fakultas Kesehatan Masyarakat Universitas Indonesia. 
N.Vinky Rahman (2004), Kebakaran, Bahaya Unpridictable, Upaya dan Kendala Penanggulangannya. Fakultas Teknik Program Studi Arsitektur Universitas Sumatra Utara.

Peraturan Menteri PU No.29/PRT/M/2006, Tentang Pedoman Persyaratan Teknis Bangunan Gedung, Departemen Jenderal Cipta Karya, Jakarta.

Peraturan Menteri PU No.45/PRT/M/2007, Tentang Pedoman Teknis Pembangunan Bangunan Gedung Negara.

Peraturan Pemerintah RI No.36 Tahun 2005, Tentang Peraturan Pelaksanaan UU No.28 Tahun 2002 Tentang Bangunan Gedung.

Peraturan Menteri PU No.25/PRT/M/2006, Tentang Pedoman Sertifikat Laik Fungsi Bangunan Gedung, Departemen Jenderal Cipta Karya, Jakarta.

Peraturan Walikota Banjarmasin No. 65 Tahun 2016 Tentang Ketentuan Penyelenggaraan Izin Mendirikan Bangunan Gedung, Sertifikat Laik Fungsi, TABG, dan Pendataan Bangunan Gedung, Banjarmasin. 